\title{
Wspomnienie o Profesorze Andrzeju Stelmachowskim
}

Dnia 6 kwietnia 2009 r. zmarł Profesor Andrzej Stelmachowski - światowej klasy uczony, wspaniały humanista, wybitny prawnik - twórca szkoły naukowej prawa rolnego, nauczyciel akademicki - wychowawca szerokiego grona profesorów i doktorów, mąż stanu - współorganizator odrodzonej Rzeczypospolitej, Człowiek szlachetny i prawy, który zbliżał ludzi, służył i uczył służby wspólnocie Polaków. Osiągnięcia naszego Drogiego Mistrza stanowić mogą wzorzec dokonań profesora uniwersytetu dla kolejnych pokoleń prawników, stąd potrzeba wyeksponowania głównych sfer działalności w Jego bogatej biografii.

\section{$x \times x$}

Andrzej Stanisław Ksawery, syn Wisławy z Majewskich i Bronisława Stelmachowskiego, urodził się 28 stycznia 1925 r. w Poznaniu. Jego ojciec był profesorem Uniwersytetu im. A.Mickiewicza oraz prezesem sądu apelacyjnego w Poznaniu; we wrześniu 1939 r. wraz z pracownikami sądu ewakuował się za Bug; tam został aresztowany przez NKWD i zamordowany najprawdopodobniej w Katyniu.

Naukę w szkole powszechnej i średniej Andrzej Stelmachowski odbywał w Poznaniu, a po wybuchu wojny kontynuował ją w gimnazjum polskim w Kownie (na Litwie), a następnie $\mathrm{w}$ ramach tajnego nauczania w Warszawie; maturę uzyskał w $1943 \mathrm{r}$. W tymże roku podjął studia w podziemnym Uniwersytecie Warszawskim; kontynuował je po wojnie w Poznaniu, uzyskując w 1947 r. tytuł magistra prawa na Wydziale PrawnoEkonomicznym Uniwersytetu im. A.Mickiewicza. W okresie wojennym, niezależnie od pracy (także fizycznej) oraz udziału w tajnym nauczaniu, Andrzej Stelmachowski był również żołnierzem Armii Krajowej.

Po studiach A. Stelmachowski podjął pracę na Uniwersytecie w Poznaniu, gdzie w 1950 r. uzyskał stopień doktora nauk prawnych; Jego promotorem był profesor Alfred Ohanowicz. Następnie przeniósł się na Uniwersytet Warszawski, gdzie uzyskał stopień kandydata nauk (w 1956 r.), a z począt- 
kiem roku 1958 powołany został na stanowisko docenta. Pracę w sądownictwie A. Stelmachowski rozpoczął jeszcze w Poznaniu; następnie był sędzią sądu powiatowego w Warszawie. W 1951 r. zrzekł się stanowiska sędziowskiego. Po zmianach politycznych roku 1956 podjął ponownie pracę w sądownictwie, jako członek Biura Orzecznictwa Sądu Najwyższego; w 1959 r. został oddelegowany do Ministerstwa Sprawiedliwości. Od 1962 r. A. Stelmachowski w działalności zawodowej skoncentrował się wyłącznie na pracy naukowej. Z końcem tego roku został powołany na stanowisko profesora nadzwyczajnego w Uniwersytecie Wrocławskim. Objęcie stanowiska profesora $\mathrm{w}$ tym Uniwersytecie było konsekwencją kuriozalnej uchwały Rady Państwa, która upoważniła przewodniczącego RP do podpisania nominacji profesorskiej A.Stelmachowskiego "pod warunkiem przedstawienia odcinka stałego zameldowania poza Warszawą". Tak „inteligentne” rozstrzygnięcie podjął osobiście Władysław Gomułka (I Sekretarz KC PZPR, członek Rady Państwa), który orzekł, iż aktywny katolik (A. Stelmachowski brał dział w pielgrzymce prawników do Częstochowy) może być wprawdzie profesorem, ale nie w Warszawie. Andrzej Stelmachowski wybrał Wrocław. Po siedmiu latach, w 1969 r. obją stanowisko profesora Uniwersytetu Warszawskiego. W 1973 r. uzyskał tytuł profesora zwyczajnego. Od 1970 roku A. Stelmachowski prowadził działalność dydaktyczną również w Filii Uniwersytetu Warszawskiego w Białymstoku, gdzie pełnił funkcję dziekana Wydziału Administracyjno-Ekonomicznego w latach 1975-1981.

Profesor Andrzej Stelmachowski jest postacią wybitną, która zasługuje na wielkie uznanie ze względu na swoją działalność na wielu polach. Jako uczony, wybitny prawnik, przedmiotem swych badań naukowych objął kilka dyscyplin prawnych - prawo cywilne, prawo rodzinne, prawo gospodarcze, a przede wszystkim prawo rolne. Dorobek naukowy Profesora legł u podstaw wyodrębnienia prawa rolnego jako nowej gałęzi prawa. Stworzył on również szkołę funkcjonalnego podejścia do prawa, skupiając wokół oryginalnej metody badawczej (badanie prawa w procesie jego stosowania) liczne grono uczniów. Zdaniem A. Stelmachowskiego: „Moc prawa tkwi nie w elementach formalnych, lecz... w wewnętrznych wartościach, które ze sobą niesie. Stara rzymska paremia: ius est ars boni et aequi jest czymś więcej niż pięknym ozdobnikiem, jest wyrazem przekonania, że są pewne granice, poza które ustawodawca wykroczyć nie powinien, że z chwilą gdy prawo sprzeniewierzy się funkcji nosiciela określonych wartości, przekształci się w swoje przeciwieństwo i stanie się bezprawiem, stanie się formą, która będzie stanowiła pozór prawa". Przytoczone słowa Profesora dobitnie wyrażają Jego filozofię prawa, akcentującą znaczenie aksjologii w tworzeniu i stosowaniu prawa. 
Jako nauczyciel akademicki i organizator życia naukowego Profesor Stelmachowski odniósł wielkie sukcesy w kształceniu kadry naukowej i organizacji zespołów badawczych. Profesor wypromował 23 doktorów; przewody habilitacyjne, pod Jego opieką, ukończyło 8 doktorów, a 5 uczniów (w tym piszący te słowa) uzyskało tytuły naukowe profesora. Aktualnie uczniowie Profesora piastują funkcje akademickie na 6 uniwersytetach. Spośród licznych funkcji organizacyjnych Profesora z wdzięcznością wspominamy stanowisko dziekana Wydziału Administracyjno-Ekonomicznego Filii Uniwersytetu Warszawskiego w Białymstoku (lata 1975-81). Ponad 30letnie związki Profesora z ośrodkiem białostockim walnie przyczyniły się do powstania samodzielnego Uniwersytetu w Białymstoku.

Kolejną sferą działania Profesora A. Stelmachowskiego, zawsze angażującego się w sprawy społeczne z troską o dobro wspólne i o ochronę słabszego, jest Jego udział w budowie demokratycznego państwa prawa w nowej Ojczyźnie. W sierpniu 1980 r. Profesor, będąc osobą znaną z opozycyjnych poglądów (był członkiem Konwersatorium „Doświadczenie i Przyszłość”), zaproszony został przez strajkujących stoczniowców do Gdańska, gdzie pełnił funkcję doradcy robotników przy zawarciu Porozumienia Gdańskiego. Od tego momentu Profesor związany był z ruchem "Solidarności", pełniąc funkcję doradcy Lecha Wałęsy i kierowniczych gremiów zarówno NSZZ "Solidarność", jak i „Solidarności Rolników Indywidualnych”. Funkcje te pełnił także, gdy "Solidarność" działała w podziemiu. Należał do twórców i uczestników obrad Okrągłego Stołu; współprzewodniczył zespołowi do spraw wsi i rolnictwa.

Przed 20 laty, w pierwszych wolnych wyborach, Profesor Stelmachowski został wybrany, jako reprezentant Ziemi Białostockiej, do Senatu Rzeczypospolitej Polskiej, który powierzył Mu godność marszałka. Jako marszałek Senatu Profesor uczestniczył w symbolicznym akcie przekazania insygniów władzy przez prezydenta Ryszarda Kaczorowskiego prezydentowi Lechowi Wałęsie. Przewodnicząc wyższej izbie parlamentu, niezwykle aktywnie i twórczo oddziaływał na przekształcenia ustroju państwa oraz systemu prawa. Dość wskazać, iż tak doniosłe rozstrzygnięcie ustrojowe jak wprowadzenie samorządu terytorialnego na szczeblu gmin zapadło z inicjatywy ustawodawczej Senatu. Profesor pełnił także funkcję Ministra Edukacji Narodowej w rządzie Jana Olszewskiego.

W ostatnich latach aktywność społeczna Profesora koncentrowała się wokół Stowarzyszenia „Wspólnota Polska”, którego był twórcą i długoletnim przewodniczącym. Dokonania Profesora wysoko oceniają Polacy na emigracji, na Zachodzie, a szczególnie na Wschodzie, czego potwierdze- 
niem jest liczny udział przedstawicieli Polonii w pożegnaniu Profesora. Dowodem uznania osiągnięć Profesora było powierzenie Mu, przez Prezydenta RP Lecha Kaczyńskiego, funkcji doradcy Prezydenta ds. Polonii.

Podkreślić również należy udział Profesora A. Stelmachowskiego w realizacji społecznych funkcji Koścoła, który odgrywał w Polsce specyficzną rolę jako struktura alternatywna wobec totalitarnej władzy. Profesor pełnił funkcję doradcy Episkopatu, reprezentował Kościół w pracach nad ustawodawstwem o stosunku Państwa do Kościoła katolickiego. Od 1987 r. był prezesem Klubu Inteligencji Katolickiej w Warszawie - jednego ze znaczących ośrodków opiniotwórczych w kraju. Kościół uhonorował Profesora godnością rycerza Rycerstwa Orderu Jasnogórskiej Bogurodzicy.

Charakteryzując twórczość i dorobek naukowy Profesora, pragnę podkreślić wszechstronność zainteresowań badawczych, obejmujących praktycznie całość systemu prawa prywatnego, a także dyscypliny oparte na konstrukcjach prawa publicznego (prawo gospodarcze, rolne). Profesor "specjalizował się" niejako w badaniu instytucji prawnych usytuowanych „na styku” kilku dyscyplin. Równie imponująca jest wielkość dokonań Profesora. Na liście Jego publikacji naukowych, obejmującej ponad 200 pozycji (ogłoszonych w kraju i za granicą), znajdują się traktaty i monografie książkowe, podręczniki, komentarze i glosy, recenzje, raporty z badań, referaty. Samych opracowań książkowych, których autorem, współautorem lub redaktorem był Profesor Stelmachowski, jest ponad czterdzieści. Liczne prace są efektem badań empirycznych, prowadzonych pod kierunkiem Profesora przez zespoły Jego uczniów z Wrocławia, Warszawy i Białegostoku.

Fundamentem doświadczeń i osiągnięć Profesora Stelmachowskiego są badania w dziedzinie prawa cywilnego. Przewodnim motywem cywilistycznej twórczości Profesora jest postrzeganie prawa jako instrumentu realizacji celów społecznych i ochrony społecznie doniosłych wartości. Drogę osiągnięć badawczych znaczą kolejne monografie i studia z zakresu cywilistyki: Przysposobienie w polskim prawie rodzinnym (1957), Istota i funkcja posiadania (1958), Kontraktacja produktów rolnych (1960), Nominalizm pieniężny a waloryzacja (Studia cywilistyczne, t. VI, Kraków 1965), Odpowiedzialność cywilna za niedobory (1966), Ewolucja autonomii woli (w: Tendencje rozwoju prawa cywilnego, 1983).

Podstawowym problemom prawa cywilnego poświęcony jest cykl traktatów z zakresu teorii tego prawa. Znaczącym wydarzeniem w rozwoju polskiej cywilistyki było pierwsze wydanie Wstępu do teorii prawa cywilnego (1969), w którym Autor zawarł refleksje dotyczące tak ważnych kwestii, jak zasady prawa cywilnego, klauzule generalne w kodeksie cywilnym, źródła 
prawa cywilnego czy problematyka osób prawnych. Drugie wydanie Wstępu do teorii prawa cywilnego miało miejsce w 1984 r. i przyniosło przewartościowanie niektórych ujęć, dokonane niewątpliwie pod wpływem świeżych doświadczeń związanych z powstaniem ruchu "Solidarności” i stanem wojennym. Ukoronowaniem cyklu jest dzieło pt.: Zarys teorii prawa cywilnego (1998), bogato uwzględniające doświadczenia i dorobek III Rzeczypospolitej w budowaniu demokratycznego państwa prawnego i gospodarki rynkowej. W podsumowaniu pracy Profesor stwierdza, że "szansą i celem prawa cywilnego winno być zbliżanie do siebie ludzi, zwłaszcza tych wszystkich, którym nie jest obojętna sprawa drugiego człowieka...". Także na emeryturze Profesor aktywnie uczestniczył w opracowaniu fundamentalnych syntez cywilistycznych, czego wyrazem są Jego poglądy na temat prawa własności (modele własności i ich uwarunkowania społeczno-ustrojowe, treść i wykonywanie prawa własności) zaprezentowane w „Systemie Prawa Prywatnego" (Tom 3, Prawo rzeczowe, pod red. T. Dybowskiego, Warszawa 2003).

Prawo rolne jest dziedziną, w której Profesor A. Stelmachowski odegrał rolę szczególną. W ciągu 50-ciu lat wyodrębniania się prawa rolnego (z prawa administracyjnego oraz cywilnego) prawo to stawało się nową gałęzią (najpierw w płaszczyźnie dydaktycznej, a później i doktrynalnej) przy stałym, twórczym, często krytycznym zaangażowaniu Profesora. Jego zasługą jest określenie przedmiotu i zakresu prawa rolnego (objęcie zakresem badań także rolnictwa indywidualnego, skazywanego w latach 1956-80 na "stopniowe socjalistyczne przekształcenia"). Jego dorobkiem jest opracowanie podstawowych konstrukcji prawnorolnych, takich jak zasady prawa rolnego, czy koncepcja własności rolniczej, rozumiana jako kompleks praw i obowiązków. Jego osiągnięciem są także konkretne rozwiązania prawne służące obronie rolnictwa indywidualnego. Dość wskazać, że wprowadzona przepisem art. 131 kc. (w 1982 r.) reguła, iż PRL gwarantuje własność i całkowitą ochronę indywidualnych gospodarstw rolnych, stanowiących trwały i równoprawny element społeczno-gospodarczego ustroju PRL, była konsekwencją realizacji Porozumień rzeszowsko-ustrzyckich, przy zawarciu których głównym doradcą „Solidarności RI” był Profesor Stelmachowski.

Mówiąc o zasługach Profesora w dydaktyce prawa rolnego, wyeksponować pragnę dwie okoliczności. Profesor jest twórcą koncepcji, a zarazem głównym współautorem podręcznika akademickiego („Prawo rolne” - 1966, 1970, 1980, 1987, „,Polskie prawo rolne na tle ustawodawstwa Unii Europejskiej" - 1994, 1997, 1999), uznawanego za podstawowy materiał dydaktyczny w tej dyscyplinie. Służył on 40. rocznikom studentów kierunków prawa i administracji. Oryginalna metoda prowadzenia ćwiczeń z prawa rolnego (z uwzględnieniem badań terenowych w środowisku wiejskim) sprawiła, 
iż dzięki Profesorowi prawo rolne - wbrew potocznym mniemaniom - jest niezwykle interesującą dyscypliną.

Dowodem szczególnego autorytetu Profesora A. Stelmachowskiego jest funkcja redaktora naukowego najnowszego podręcznika „Prawo rolne” (Wyd. Prawnicze Lexis Nexis 2003; wydanie 4 - 2008), będącego w zamyśle próbą zintegrowania zarówno środowiska, jak i programów nauczania prawa rolnego (wraz z powstającym prawem żywnościowym). Podręcznik ten powstał z inicjatywy Polskiego Stowarzyszenia Prawników Agrarystów (którego honorowym przewodniczącym był Profesor), a przygotowany został przez 20 współautorów z 9-ciu uniwersytetów. Podręcznik ten ma rzeczywiście ogólnopolski charakter.

O uznaniu pozycji Profesora w skali międzynarodowej świadczą Jego artykuły $\mathrm{w}$ renomowanych czasopismach zagranicznych, zaproszenia do udziału w konferencjach i towarzystwach naukowych, przede wszystkim zaś doktoraty honorowe Uniwersytetu Paris I Pantheon-Sorbonne oraz Uniwersytetu w Ferrarze, a także prestiżowe członkostwo w Akademie de l'Agriculture de France. Profesor był pierwszym polskim uczonym w Europejskim Komitecie Prawa Rolnego (CEDR); dzięki Jego staraniom i autorytetowi Polskie Stowarzyszenie Prawników Agrarystów zostało podniesione do rangi sekcji krajowej Europejskiego Komitetu Prawa Rolnego.

Działalność naukowo-dydaktyczna i służba publiczna Profesora miała miejsce głównie w Warszawie i Uniwersytecie Warszawskim. W biografii Profesora chwalebnie zapisał się także okres wrocławski (lata 1962-69), gdzie Profesor należał do wybitnych twórców ośrodka prawniczego na Uniwersytecie. Także Białystok był miejscem aktywnej, pionierskiej działalności Profesora, który współtworzył środowisko naukowe Wydziału Administracyjno-Ekonomicznego, później zaś - Wydziału Prawa Filii Uniwersytetu Warszawskiego, i walnie przyczynił się do powstania Uniwersytetu w Białymstoku. Podziękowaniem za zasługi Profesora dla tych środowisk naukowych jest przyznanie $\mathrm{Mu}$ tytułu doktora honoris causa Uniwersytetu w Białymstoku (1999 r.) oraz tytułu doktora honoris causa Uniwersytetu Wrocławskiego (2005 r.). Profesor jest również doktorem honorowym Uniwersytetu Kardynała Stefana Wyszyńskiego w Warszawie (2003 r.).

Profesor Andrzej Stelmachowski jest twórcą nowej szkoły naukowej prawa rolnego, albowiem swoim dorobkiem naukowym przygotował podstawy teoretyczne do wyodrębnienia (w płaszczyźnie doktrynalnej i dydaktycznej) prawa rolnego jako odrębnej gałęzi; zaproponował oryginalną metodę badawczą - badanie prawa w procesie jego stosowania, i wokół tych 
idei zorganizował zespół badawczy - liczne grono uczniów w ośrodkach wrocławskim, warszawskim i białostockim.

W uznaniu zasług dla rozwoju nauki prawa, dla budowy demokratycznego państwa prawnego oraz dla kształtowania kultury prawnej narodu Profesor Andrzej Stelmachowski odznaczony został Krzyżem Wielkim Orderu Odrodzenia Polski oraz - pośmiertnie - Orderem Orła Białego.

We wszystkich dziedzinach swojego zaangażowania, pomimo zmian zachodzących w zewnętrznym otoczeniu, Profesor A. Stelmachowski prezentował zawsze trwały system wartości, wśród których wymienić trzeba: prawość, wierność przekonaniom i odpowiedzialność, troskę o dobro wspólne, solidarność ze słabszym i kierowanie się społeczną nauką Kościoła, co zapewniło Mu niekwestionowany autorytet moralny człowieka o wielkiej sile charakteru, wyrozumiałego wszakże dla ludzkich słabości.

Przyjemnością było znać Profesora, przywilejem - współpracować z nim, a szczęściem - należeć do grona uczniów, dla których był Mistrzem, ale i coraz bardziej Przyjacielem. Mistrz był wspaniałym, mądrym, spełnionym człowiekiem; dzięki Jego wiedzy i wsparciu wyszliśmy „na ludzi”.

\section{$x \times x$}

Uroczystości pożegnalne Profesora Andrzeja Stelmachowskiego miały miejsce 15 kwietnia br. w Bazylice Archikatedralnej Św. Jana Chrzciciela (koncelebrowaną Mszę żałobną odprawił Kardynał Józef Glemp, Prymas Polski) oraz na Starych Powązkach (mowy pożegnalne wygłosili: Prezydent RP Lech Kaczyński, Marszałek Senatu RP Bogdan Borusewicz, Prezes Stowarzyszenia „Wspólnota Polska” Maciej Płażyński oraz Dziekan Wydziału Prawa UW prof. Krzysztof Rączka). Wokół mogiły zgromadziła się ogromna rzesza ludzi pogrążonych w smutku; każdemu z nich Profesor coś z Siebie pozostawił.

Dziękujemy!

Stanistaw Prutis

Uniwersytet w Biatymstoku 